\title{
"A Study to Assess the Effectiveness of Structured Teaching Planning On Knowledge of Women Age Group of 30-65 Years Regarding Cervical Cancer at Chandar Nagar, Dehradun Uttarakhand.
}

\author{
Mamta Kaparwan ${ }^{1}$, Reshma, Pooja, Ruchi ${ }^{2}$ \\ ${ }^{I}$ community, State College Of Nursing/Hnbmu, India \\ ${ }^{2}$ P.B.Bsc.Students, State College Of Nursing/Hnbmu, India
}

\begin{abstract}
Dehradun. Statement was taken as a study to assess the effectiveness of structured teaching programme on knowledge of women of age 30-60 years regarding cervical cancer. Objective were to know the level of knowledge before and after administration of structured teaching program, Researcher used Pender health promotion model as conceptual frame work by the using of quantitative Research approach with pre experimental research design, sample size were 60.Research found in pre-test $-25 \%$ women have inadequate level of knowledge and $8.33 \%$ have adequate level of knowledge. After administration of structured teaching programme level of knowledge increased as $100 \%$ adequate knowledge. Researcher found effectiveness of structured teaching program significant by the using to 't' test (18.65) at level of $P<0.05$.
\end{abstract}

\section{Introduction}

Cervical Cancer is a arising from the cervix.It is due to the abnormal growth of cells that have the ability to invade or spread to the other part of the body. Early on typically no symptoms are seen. Later symptoms may include abnormal vaginal bleeding, pelvic pain during sexual intercourse.

About $70 \%$ of cervical cancer occurs in developing countries. In low income countries it the most common cause of cancer death. Cervical cancer is the second most common cancer among women and is the primary cause of cancer related death in developing countries. There has been a regular campaign against cervical cancer for 30 years in India but this had a little impact on the morbidity and mortality from the disease.

Early detection of cervical cancer remains a dream in India even after ten years the introduction of vaccine available to prevent cervical cancer. Over 62,000 women died of cervical cancer in 2015, accounting for $24 \%$ of total cancer related death of women in India.

\section{Need Of The Study}

"You will come to learn a great deal if you study the insignificant in depth"

A study conducted by the New England journal of medicine reveals that about 1.3 lakhs new cases of cervical cancer are reported every year in India and about a quarter of the 5 lakh cases globally. Experts point out that women need to be sensitized to curve the growth of the disease. Even the educated class are not aware of cervical cancer and given link it with the net.We have to explain to them that cervical cancer in the lower part of the body: says Gynaecologist- SunitaVerma.

Cancer Research foundation of India (CRFI) - a recently constituted body of actively involved in spreading awareness, Dr Siddharth Shania, Co- Founder, CRFI says, "Awareness, prevention and Detection is what we are striving for to deal with the cancer. We need to Reach out to both grass roots and urban India" Cancer of the cervix is the most important cancer in women in India over the past two decades. It accounted for $16 \%$ of all cancer in women in the urban registries in 2005 . Over $70 \%$ of population of India resides in rural areas, cervical cancer still constitute the number on cancer among female.

\section{Objectives}

1. To assess the pre- test level of knowledge regarding cervical cancer among the women age group 30-65 years.

2. To administer structured teaching program about cervical canceramong the women age group 30-65 years.

3. To assess the effectiveness of S T P on knowledge regarding cervical cancer among

Women among the women age group 30-65 years.

4. To assess the association between per-test their related demographic variables. 


\section{Hypothesis}

H1: There will be a significant difference between per-test\& post-test levels of knowledge regarding cervical cancer among the women age group 30-65 years at chandanagar,dehradun.

$\mathrm{H} 2$ :- There will be a significant association between per-test knowledge and their demographic variables.

\section{Review Of Literature}

Peter and Navkiran (2009) Conduct a cross sectional survey on Knowledge and health benefit regarding cervical cancer screening among college students of Ghana, Thus samples comprise of 140 women aged 20-35 years which revealed that only $7.9 \%$ of the women were aware about the link between human papilloma Virus(Human Population Virus) and cervical cancer. Only 12 women underwent pap test. The commonest barrier for not undergoing screening was not knowing where to go(24.37), belief that the test is painful (9.4\%) and that every one may that they are sexually active(24.6\%).

According to the surveillance epidemiology and report (SEER) from 2000-2004, the median age diagnosis for cancer of the cervix was 48 years of age (National Cancer Institute-2007).

\begin{tabular}{|l|l|}
\hline Age(In Year) & Percentage \\
\hline 20 & 01 \\
\hline $20-34$ & 15 \\
\hline $35-44$ & 26 \\
\hline $45-54$ & 23 \\
\hline $55-64$ & 15 \\
\hline $65-74$ & 10 \\
\hline $75-84$ & 07 \\
\hline $85+$ years & 03 \\
\hline
\end{tabular}

Another subgroup at risk for HIV and cervical cancer in college women. College age women are all at greater risk of contracting sexually transmitter infection than the general population because of the high risk sexual behaviour in which they engaged (Ingleductal-2014)

Mishra JS, Shrivastava S, Singh U, Srivastava AN 2009 adopted an exploratory design research to assess the knowledge and practice regarding cervical cancer among 100 married women between the age 20-60 Years at Indor(M.P.) using purposive sampling.The investigation used a structured questioners of an item to assess the knowledge regarding early diagnose and prevention of cervical cancer.

Reliability wow calculated using split half method and the ' $r$ 'value was 0.8 . The revealed that all of subjects $100(100 \%)$ hand no knowledge regarding early diagnosis and prevention of cervical cancer.14(14\%) of them at moderate risk for developing cervical cancer. Hence the conclusion was made by saying that there is a need of creating public awareness regarding the benefits provided by the government through various health scheme and all government hospitals must make these schemes available to the Population. Nurses should also be trained through in-servicer education to spread the health awareness to the individual and families.

Ali SF 2010A Conducted a cross sectional, interview based survey was conducted in 3 major teaching hospital in Karachi in regarding the knowledge and awareness of cervical cancer among 400 females interns and nursing staff.Convenience sampling was applied using questioner's method. Of all the interviewConducted $1.8 \%$ did not know cervical cancer as a disease, $28.3 \%$ of the respondents were aware that cervical cancer is the most common disease of gynaecological cancer and $26 \%$ knew it is second in rank in mortality. $78 \%$ were aware that the virus human papillomaVirus.Majority recognize that it is sexually transmitted but only a minority (41\%) knew that it can be detected by PCR. Only $26 \%$ of the study population was one or more risk factors. This study serves to highlights that the majority of working health professionals are not adequately equipped to knowledge concerning cervical cancer. Continuing progress should be started at the hospital level among to conference to spread Knowledge.

According to WHO 2006, Over the past three decades cervical cancer rates have fallen in most of the developed world. In contrast the death rate in most developing countries have risen or remain unchanged (WHO 2006)

\section{Conceptual Framework}

Conceptual framework by using health promotion [BY PENDER]. The health promotion model [HPM] proposed by Pender[1982,revised 1996] was designed to be a "Complimentary counterpart to the models of health protection and it defines as health as a positive, dynamic state,not merely the absence of disease[Pender and Other,2002]".

The Model focuses on the following three areas-

1. Individual characteristics and experiences

2. Behaviour, specific knowledge and affect

3. Behavioural outcome 


\section{Methodology}

Methodology includes description of research approach, research design,study setting description and development of tool and plan for analysis.

6.1. Research Approach

Quantitative research approach was considered to be the most appropriate for present study.

6.2. Research Design

Pre-experimental design is adopted for the study that focuses on obtaining information regarding knowledge related to prevention and treatment of cervical cancer.

\begin{tabular}{|l|l|l|l|}
\hline Group & Pre-assessment & Intervention & Post-assessment \\
\hline Experimental & O1 & X & O2 \\
\hline
\end{tabular}

6.3. Sample and Sample Size

60 women who fulfil the inclusion criteria are taken as sample of this study.

6.4. Sampling Technique

Non-probability purposive sampling technique was used as we choose the homogenous population based on age i.e. $30-65$ years.

6.5. Settingof the study

This study was conducted at Chandarnagar,Dehradun.

6.6. Variables

6.6.1. Independent Variables: Structured teaching programme.

6.6.2. Dependent variables: Knowledge of women regarding cervical cancer and its preventions.

6.6.3. Socio-demographic variables: Age,occupation,education,monthly income,source of information

6.7. Data collection tool

Tool 1: Contains demographic variables data.

1. Age

2. Occupation

3. Education

4. Income

5. Source of information

Tool 2: Structured knowledge questionnaire about treatment and prevention of cervical cancer. It consists of 40 questions on cervical cancer.

\section{Interptation of Data}

Table 1Assessment of pre-test and post-test level of knowledge of women age group 30-65 years.

\begin{tabular}{|l|l|l|l|l|}
\hline Level of knowledge & Pre-test & Post-test \\
\hline \multirow{2}{*}{ Inadequate $(<50 \%)(1-12)$} & $\mathrm{F}$ & $\%$ & $\mathrm{~F}$ & $\%$ \\
\hline Moderate(50-75\%)(13-24) & 15 & $25 \%$ & 0 & 00 \\
\hline Adequate(>75\%)(25-37) & 40 & $66.66 \%$ & 0 & 00 \\
\hline
\end{tabular}

Table 2 depicts In Pre-test 25\% have inadequate level of knowledge and $8.33 \%$ have adequate knowledge and in post-test $100 \%$ subject have adequate level of knowledge regarding cervical cancer.

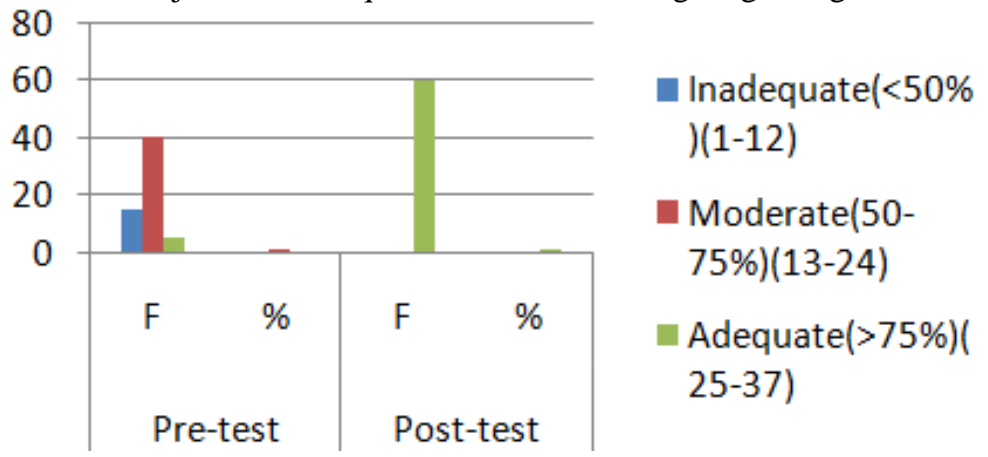

Table 2 Effectiveness of structured teaching programme on knowledge regarding cervical cancer among women age group 30-65 years in Chandarnagar,Dehradun.

\begin{tabular}{|l|l|l|l|c|}
\hline OVER ALL KNOWLEDGE & Mean & SD & "t"value & Interference \\
\cline { 1 - 4 } Pre-test & 16.98 & 0.122 & 18.65 & \multirow{2}{*}{$*$ *df=59 } \\
\hline Post-test & 32.28 & 0.58 & $*$ \\
\hline
\end{tabular}

*Level of significant at $\mathrm{p}<0.05$ 
“ A Study to assess the effectiveness of structured teaching planning on knowledge of women...

The table revels that post-test mean for knowledge score is significantly higher than the pre-test mean score. The statistical paired " $t$ "test for knowledge found to be 18.65 that mean intervention in highly significant

Table 3: Association between the knowledge levels of women age group 30-65 years with their socio-demographic variables

\begin{tabular}{|c|c|c|c|c|c|c|c|c|c|}
\hline \multirow[t]{2}{*}{$\begin{array}{l}\text { Socio-demographic } \\
\text { variables }\end{array}$} & \multicolumn{2}{|c|}{$\begin{array}{l}\text { INADEQUATE } \\
(1-12)\end{array}$} & \multicolumn{2}{|c|}{$\begin{array}{l}\text { MODERATE } \\
(13-24)\end{array}$} & \multicolumn{2}{|c|}{$\begin{array}{l}\text { ADEQUATE } \\
(25-37)\end{array}$} & \multirow[t]{2}{*}{ Df } & \multirow[t]{2}{*}{$\mathrm{X}^{2}$} & \multirow[t]{2}{*}{ Significant } \\
\hline & $\mathrm{F}$ & $\%$ & $\mathrm{~F}$ & $\%$ & $\mathrm{~F}$ & $\%$ & & & \\
\hline $\begin{array}{l}\text { Age } \\
30-40 \\
41-50 \\
51-60 \\
>60 \\
\end{array}$ & $\begin{array}{l}11 \\
1 \\
4 \\
0\end{array}$ & $\begin{array}{l}30.55 \% \\
8.33 \% \\
36.36 \% \\
0 \%\end{array}$ & $\begin{array}{l}22 \\
9 \\
7 \\
1\end{array}$ & $\begin{array}{l}61.11 \% \\
75 \% \\
63.63 \% \\
100 \%\end{array}$ & $\begin{array}{l}3 \\
2 \\
0 \\
0\end{array}$ & $\begin{array}{l}8 \% \\
16.6 \% \\
0 \% \\
0 \%\end{array}$ & 6 & 12.65 & $*$ \\
\hline $\begin{array}{l}\text { Education } \\
\text { Illiterate } \\
\text { Primary } \\
\text { Senior } \\
\text { Secondary } \\
\text { Bachelor } \\
\end{array}$ & $\begin{array}{l}7 \\
5 \\
4 \\
0\end{array}$ & $\begin{array}{l}35 \% \\
23.8 \% \\
36.3 \% \\
0 \%\end{array}$ & $\begin{array}{l}13 \\
14 \\
6 \\
6\end{array}$ & $\begin{array}{l}65 \% \\
66.66 \% \\
54.54 \% \\
75 \%\end{array}$ & $\begin{array}{l}0 \\
2 \\
1 \\
2\end{array}$ & $\begin{array}{l}0 \% \\
9.52 \% \\
9.09 \% \\
25 \%\end{array}$ & 6 & 7.72 & NS \\
\hline $\begin{array}{l}\text { Occupation } \\
\text { Home maker } \\
\text { Dialy wages } \\
\text { Govt.job } \\
\text { Business }\end{array}$ & $\begin{array}{l}13 \\
3 \\
0 \\
0\end{array}$ & $\begin{array}{l}25 \% \\
100 \% \\
0 \% \\
0 \%\end{array}$ & $\begin{array}{l}33 \\
0 \\
3 \\
2\end{array}$ & $\begin{array}{l}63.46 \% \\
0 \% \\
100 \% \\
100 \%\end{array}$ & $\begin{array}{l}6 \\
0 \\
0 \\
0\end{array}$ & $\begin{array}{l}11.53 \% \\
0 \% \\
0 \% \\
0 \%\end{array}$ & 6 & 10.58 & NS \\
\hline $\begin{array}{l}\text { Income } \\
<5000 \\
5000-10000 \\
10000- \\
15000 \\
>15000\end{array}$ & $\begin{array}{l}9 \\
4 \\
2 \\
2\end{array}$ & $\begin{array}{l}45 \% \\
20 \% \\
16.66 \% \\
25 \%\end{array}$ & $\begin{array}{l}10 \\
16 \\
7 \\
4\end{array}$ & $\begin{array}{l}50 \% \\
80 \% \\
58.33 \% \\
50 \%\end{array}$ & $\begin{array}{l}1 \\
0 \\
3 \\
2\end{array}$ & $\begin{array}{l}5 \% \\
0 \% \\
25 \% \\
25 \%\end{array}$ & 6 & 11.762 & NS \\
\hline $\begin{array}{l}\text { Source of } \\
\text { information } \\
\text { Health } \\
\text { Worker } \\
\text { Social Media } \\
\text { Television } \\
\text { News Paper }\end{array}$ & $\begin{array}{l}3 \\
2 \\
10 \\
1\end{array}$ & $\begin{array}{l}21.42 \% \\
16.66 \% \\
34.48 \% \\
20 \%\end{array}$ & $\begin{array}{l}9 \\
9 \\
15 \\
4\end{array}$ & $\begin{array}{l}64.28 \% \\
75 \% \\
51.72 \% \\
80 \%\end{array}$ & $\begin{array}{l}2 \\
1 \\
4 \\
0\end{array}$ & $\begin{array}{l}14.28 \% \\
8.3 \% \\
13.79 \% \\
0 \%\end{array}$ & 6 & 3.25 & $\mathrm{NS}$ \\
\hline
\end{tabular}

*Level of significant a $\mathrm{p}<0.05$

NS= Non Significant

\section{Conclusion}

From the finding of present study, it is conclude that the level of knowledge regarding cervical cancer among women age group 30-65 years at Chandar Nagar, Dehradun, were moderate in experimental group during the pre-test assessment. However, the finding of the post-test in experimental group, the level of knowledge was improved and the score has indicated an adequate level of knowledge among women at Chanadar Nagar, Dehradun. The improvement is due to administration of self-structured teaching programme. Therefore the knowledge of women age group 30-65 years at Chandar Nagar can be further improved by providing such teaching programme regularly.

8.1. Implication of the study

The finding of the study has implications related to nursing education, nursing practice, nursing research and nursing administration regarding the increase in the knowledge related to cervical cancer among women age group 30-65 years at ChanderNagar, Dehradun.

8.2 Recommendation for further study

- A similar study can be undertaken with a control group design.

- The present study can be repeated in similar and different setting with largersample to validate and generalize finding of the study.

- A similar study can be conducted among women of different community.

- A study can be conducted to assess the knowledge of the community healthworkers regarding knowledge of cervical cancer.

- Various other intervention modalities, which may vary in content and method,can be used to assess the effectiveness of STP among women in community. 


\section{Acknowledgement}

We are grateful to almighty God for showering his grace blessing guidance and support which strengthened us in the Research Process and sustained us throughout this endeavor. The present study has been undertaken and completed under the inspiring and valuable guidance and supervision of our guide Mrs. MamtaKaparwan, M.sc (N), Assistant Professor, State College of Nursing Dehradun, Uttarakhand. We express our deep sense of gratitude to her for her expert guidance, valuable suggestion, encouragement and keen interest in the conception, planning and execution of the study. She was always available for discussion and guidance. We consider it a great honour and privilege to have completed the study under her supervision. We are highly obligated to my parents and family members who are the source of inspiration throughout our study. We would like to thank our family member for their support during the study. Lastly but not the least, we gratefully remember and dedicate this number piece of work to all the "respondents" who participated in study and help it to progress without difficulties. Before we conclude we thank our Lord for his abundant love and mercy, an unseen presence and guidance throughout study.

\section{Books}

\section{References}

[1]. Bruner and siddhartha'stextbook of medical and surgical nursing11 edition,published by -Walters Kluwer (India) PVtLtd,page no. $1625,1682-1685$

[2]. PHIPPs Medical sergical nursing $8^{\text {th }}$ edition,mosbyElsevier,page no. 1697-1707.

[3]. Debera S. Prescher- Huges, clinical practice, protocols in oncology Nursing John and Bartlett publisher,page no.150-151.

[4]. Jocer M. Black,JaneHokanson Hawks Medical surgical Nursing $8^{\text {th }}$ edition Saunders Elsevier,Page no.921

[5]. D.C.Dutta,text book of gynaecology,New central book agency (P)ltd.,page no 327.

[6]. D.C.Dutta,"text book of Obstetrics.Including perinatology and contraception.New central book agency(p).ltd page no. 5-9.

[7]. B.T. Basavanthappa,Medical surgical Nursing, $2^{\text {nd }}$ edition Jaypee brothers Publisher(p)ltd. Page no,258.

[8]. Ross Marie nicswiadomy. Foundation of Nursing research. $5^{\text {th }}$ edition,darlingkindersler (India)pvt ltd. Licenseer of person education in south asia.page no-60.132-134.381.

[9]. T.K.IndraniResearch methodology for nurses, $1^{\text {st }}$ edition.Jaypee Brothers Medical Publisher,pvtltd.page no-45-47.

[10]. Denise f.Polit Cheryl tatana beck Essential of Nursing research appraising evidence for nursing practice $7^{\text {th }}$ edition,page no 68,232 234,295,74-75.

[11]. B.T. BasavanthapaNursing research.2 ${ }^{\text {nd }}$ edition Jaypee Brothers Medical Publisher,Page no. 108-109,223,464-473.

[12]. B.K. MahajanMethods in Bio-statistic

[13]. Websites

[14]. www.digitalcommons.usu.edu

[15]. www.rguhs.ac.in

[16]. $\quad$ www.tigerprints.deinson.edu/all_dissertations 